\title{
Depression and its associated factors among people living with HIV/AIDS attending the HIV/AIDS CLINIC in southwest Nigeria
}

\author{
OLUREMI E, ADEWOLE ${ }^{A, B, E-G}$, OLAWUNMI A. OLAGUNDOYE ${ }^{A, C-E}$, IBIJOKE O. AJUMOBI ${ }^{A, G}$ \\ ORCID ID: 0000-0002-1697-1720
}

Department of Family Medicine, General Hospital, Lagos, Lagos State Health Service, Commission, Lagos, Nigeria

A - Study Design, B - Data Collection, C - Statistical Analysis, D - Data Interpretation, E - Manuscript Preparation, F - Literature Search, G - Funds Collection

Summary Background. Mental health disorders have received little attention amongst people living with HIV/AIDS (PLWHA). Depression is the most common psychiatric consequence of HIV/AIDS diagnosis. Its prevalence is higher among PLWHA than the general population.

Objectives. To determine the prevalence of depression, to identify its associated factors and, lastly, to determine its association with treatment outcome measures among PLWHA on antiretroviral therapy (ART) aged $\geq 18$ years receiving care at the HIV clinic of General Hospital, Lagos.

Material and methods. A cross-sectional study was conducted using the systematic random sampling method to select participants over a period of 14 weeks. An interviewer-administered questionnaire was designed to capture socio-demographic, behavioural, psychosocial, HIV and health-related information, as well as the clinical data of the participants. The Patient Health Questionnaire (PHQ-9) was used to assess depression. The relationships between depression and other participants' characteristics were tested with Pearson's chi-squared $\left(\chi^{2}\right)$ test. Logistic regression analysis was used to minimise confounding, and the level of statistical significance was set as a $p$-value of $\leq 0.05$.

Results. The total of 279 respondents, with a mean age of $43.1 \pm 10.3$ years, were predominantly females $(67.7 \%)$. The prevalence of depression among the participants was $24 \%$. Factors such as occupation ( $p=0.041 ; 95 \% \mathrm{Cl}, 0.43$ to 3.63$)$, alcohol intake $(p=0.036 ; 95 \%$ $\mathrm{Cl}, 0.62$ to 3.82$)$, cohabitation ( $p=0.025 ; 95 \% \mathrm{Cl}, 1.43$ to 3.82$)$, stigmatisation $(p=0.008 ; 95 \% \mathrm{Cl}, 0.92$ to 3.70$)$ and personal history of depression ( $p<0.001 ; 95 \% \mathrm{Cl}: 1.75$ to 6.38 ) showed statistically significant relationships with depression.

Conclusions. The burden of depression is high among PLWHA. Identifying and unravelling factors associated with depression among PLWHA and advocacy against stigmatisation will play a significant role in reducing this burden.

Key words: depression, mental health, HIV, Acquired Immune Deficiency Syndrome, treatment outcome.

Adewole OE, Olagundoye OA, Ajumobi IO. Depression and its associated factors among people living with HIV/AIDS attending the HIV/ /AIDS CLINIC in southwest Nigeria. Fam Med Prim Care Rev 2021; 23(1): 7-12, doi: https://doi.org/10.5114/fmpcr.2021.103149.

\section{Background}

Mental illness is one of the co-morbidities that are often overlooked in treating patients with Human Immunodeficiency Virus/Acquired Immunodeficiency Syndrome (HIV/AIDS) [1]. Depression and HIV/AIDS are projected to become the world's two leading causes of disability by 2030 [2]. Globally, depression affects more than 300 million people, and this accounts for 121 million People Living with HIV/AIDS (PLWHA) [3]. The average prevalence of depression in low and middle-income countries and sub-Saharan Africa is about 10-20\% [4]. In Nigeria, depression is five times more common in people living with HIV/AIDS than an apparently healthy population [5].

Depression is second to substance abuse as the most prevalent psychiatric disorder among HIV positive patients [6]. Despite its high prevalence, it is commonly under-diagnosed and consequently untreated [7].

There is widespread stigmatisation against mental illness in Nigerian communities [8]. This is doubld for PLWHA, as the stigma has also been shown to be associated with HIV/AIDS [9]. Depression silently destroys families and ruins the careers of affected individuals [10]. It adds to the burden of the disease experienced by patients with HIV and increases the risk of morbidity and mortality [11]. Several factors such as social stigma, occupational disability, poor social support, long term physical discomfort and illness have also been attributed to the increasing rate of depression among PLWHA [12].
Sub-Saharan Africa remains the centre of the HIV/AIDS epidemic [13]. However, as life expectancy increases for people living with HIV in this region, more attention is being paid to the impact of co-morbid non-communicable disorders. Much has been written about the importance of certain NCDs in PLWHA, but little attention has been given to the significant mental health burden [14].

There is increasing evidence that depression negatively impacts the course of HIV/AIDS [14]. Although studies done in these areas have identified factors associated with depression, only a few have considered the impact of depression on the treatment outcome measure (CD4 count) of these patients in Nigeria $[15,16]$. Thus, this study extends knowledge by addressing the question of whether depression is associated with socio-demographic, behavioural, psychosocial or health-related factors among PLWHA in the study setting.

\section{Material and methods}

\section{Study design}

A descriptive cross-sectional study was conducted at the HIV clinic of the premier general hospital in Nigeria.

\section{Study setting}

General Hospital, Lagos is a 225-bed hospital that provides primary and secondary health care services. 
The HIV/AIDS clinic had a total of 7,420 patients registered at the clinic; however, only 3,953 of them remained enrolled for Anti-Retroviral Therapy (ART) at the facility. From the clinic register, it was observed that 3,632 patients had been on ART for at least six months. The average daily attendance of patients on ART for at least six months was 61.

\section{Study population}

The study population was made up of HIV-positive clients aged 18 years and above receiving care at the HIV clinic in General Hospital, Lagos.

\section{Sample size estimation}

The minimum sample size of 279 was determined from the formula developed by Cochran [17] to yield a representative sample for categorical data. The correction formula was further applied for the study population which, was $<10,000$. At a $95 \%$ confidence level, desired precision of $5 \%$ and a prevalence value of $23 \%$ for depression among PLWHA from a previous study done in southwest Nigeria, a minimum sample size of 279 was derived.

\section{Selection criteria}

Participants were consenting HIV-positive clients aged 18 years and above who had been on ART for at least six months. Patients who were acutely ill or debilitated and those with chronic physical/mental conditions such as diabetes, hypertension or other psychiatric disorders (such as schizophrenia, bipolar affective disorders, etc.) were excluded.

\section{Sampling technique}

The minimum sample size of 279 was achieved through a systematic sampling technique to select the participants from the potential respondents who met the inclusion criteria. The sampling interval (13) was determined as the ratio of the average estimated population size over a 14-week study period $(3,632)$ and the minimum sample size (279) [18]. The first participant was selected by simple random sampling (ballot method). Others were sequentially selected based on the sampling interval (13).

\section{Materials}

A seven-part questionnaire was designed to capture data regarding socio-demographic characteristics, behavioural variables, HIV and health-related information, as well as clinical measurements. A validated tool, the Patient Health Questionnaire (PHQ-9), was included in the interviewer-administered questionnaire. Patient Health Questionnaire scores are interpreted as follows: 5-9, 10-14, 15-19 and 20-27, which represent cut-off points for mild, moderate, moderately severe and severe depression, respectively [19].

\section{Data analysis}

The data obtained was recorded into a computer and analysed using Statistical Package for Social Sciences (SPSS) version 21 (IBM SPSS Statistics by IBM). The prevalence rates of the categories of depression based on severity was calculated and presented in a frequency table. The relationships between factors associated with depression, such as the socio-demographic, behavioural, psychosocial variables, as well as CD4 count, were determined using the Pearson's chi-squared $\left(\chi^{2}\right)$ test. Binary logistic regression analysis was used to analyse factors that showed a statistically significant relationship with depression. Fisher's exact test was applied for bivariate analysis where the cell count was less than 5 . The level of statistical significance was set as a $p$-value of equal or less than 0.05 .

\section{Ethical consideration}

Ethical approval to conduct the study was granted by the hospital's ethics review committee.

The purpose of the study was explained to the participants and written informed consent was obtained before administration of the questionnaire. The privacy and confidentiality of respondents and anonymity were ensured. There were no anticipated risks to participants. Participants who screened positive for depression were referred for further psychiatric evaluation and treatment.

\section{Results}

A total of 279 participants with a mean age of $43.1 \pm 10.3$ participated in the study. The majority $(53.4 \%)$ were young adults ( $<45$ years of age). Of the participants, more than two-thirds (66.7\%) were females, more than half (59.9\%) were married, and most (74.9\%) were from monogamous family settings. Nearly half of the participants had secondary education (43.7\%), most (72\%) lived above the poverty line, and $70.2 \%$ were employed.

Almost a quarter of the participants were depressed (prevalence rate $=24 \%(\mathrm{Cl}: 65.8-68.2))$.

The relationships between the socio-demographic characteristics of the participants and the presence of depression are shown in Table 1, while Table 2 depicts the relationships between the behavioural/psychosocial characteristics of the participants and depression. There was a statistically significant relationship between depression and the following: occupation $(p=0.016)$, alcohol intake $(p=0.012)$, cohabitation $(p=0.007)$, stigmatisation $(p=0.003)$, having a family member with $\operatorname{HIV}(p=$ $0.047)$ and personal history of depression $(p=0.001)$.

\begin{tabular}{|c|c|c|c|c|}
\hline \multirow[b]{2}{*}{ Variable } & \multicolumn{2}{|c|}{ Presence of depression } & \multirow[b]{2}{*}{$x^{2}$} & \multirow[b]{2}{*}{$p$} \\
\hline & $\begin{array}{l}\text { No } \\
n=212(\%)\end{array}$ & $\begin{array}{l}\text { Yes } \\
n=67(\%)\end{array}$ & & \\
\hline $\begin{array}{l}\text { Age in years } \\
\text { young adults } \\
(<45) \\
\text { middle-aged } \\
\text { adults }(45-60) \\
\text { elderly }(60+)\end{array}$ & $\begin{array}{l}107(50.5) \\
97(45.7) \\
8(3.8)\end{array}$ & $\begin{array}{l}42(62.7) \\
24(35.8) \\
1(1.5)\end{array}$ & & $0.192^{*}$ \\
\hline $\begin{array}{l}\text { Gender } \\
\text { male } \\
\text { female }\end{array}$ & $\begin{array}{l}63(29.7) \\
149(70.3)\end{array}$ & $\begin{array}{l}27(40.3) \\
40(59.7)\end{array}$ & 2.608 & 0.106 \\
\hline $\begin{array}{l}\text { Marital status } \\
\text { single } \\
\text { married } \\
\text { divorced } \\
\text { separated } \\
\text { widowed }\end{array}$ & $\begin{array}{l}31(14.6) \\
129(60.9) \\
3(1.4) \\
24(11.3) \\
25(11.8)\end{array}$ & $\begin{array}{l}14(20.9) \\
38(56.7) \\
2(3.0) \\
6(8.9) \\
7(10.5)\end{array}$ & & $0.657^{*}$ \\
\hline $\begin{array}{c}\text { Family setting } \\
\text { monogamy } \\
\text { polygamy }\end{array}$ & $\begin{array}{l}157(74.1) \\
55(25.9)\end{array}$ & $\begin{array}{l}52(77.6) \\
15(22.4)\end{array}$ & 0.342 & 0.558 \\
\hline $\begin{array}{l}\text { Religion } \\
\text { Christianity } \\
\text { Islam } \\
\text { traditional } \\
\end{array}$ & $\begin{array}{l}146(68.9) \\
64(30.2) \\
2(0.9) \\
\end{array}$ & $\begin{array}{l}48(71.6) \\
19(28.4) \\
0(0.0) \\
\end{array}$ & & $0.930 *$ \\
\hline $\begin{array}{l}\text { Ethnicity } \\
\text { Yoruba } \\
\text { Igbo } \\
\text { Hausa } \\
\text { others }\end{array}$ & $\begin{array}{l}123(58.0) \\
48(22.6) \\
11(5.2) \\
30(14.1)\end{array}$ & $\begin{array}{l}33(49.3) \\
19(28.4) \\
5(7.4) \\
10(14.9)\end{array}$ & 1.872 & 0.599 \\
\hline
\end{tabular}




\begin{tabular}{|c|c|c|c|c|}
\hline \multirow[b]{2}{*}{ Variable } & \multicolumn{2}{|c|}{ Presence of depression } & \multirow[b]{2}{*}{$\chi^{2}$} & \multirow[b]{2}{*}{$p$} \\
\hline & $\begin{array}{l}\text { No } \\
n=212(\%)\end{array}$ & $\begin{array}{l}\text { Yes } \\
n=67(\%)\end{array}$ & & \\
\hline $\begin{array}{l}\text { Domicile } \\
\quad \text { within Lagos } \\
\text { outside Lagos }\end{array}$ & $\begin{array}{l}208(98.1) \\
4(1.9) \\
\end{array}$ & $\begin{array}{l}64(95.5) \\
3(4.5) \\
\end{array}$ & & $0.364^{*}$ \\
\hline $\begin{array}{l}\text { Education } \\
\text { none } \\
\text { primary } \\
\text { secondary } \\
\text { tertiary }\end{array}$ & $\begin{array}{l}20(9.4) \\
43(20.3) \\
95(44.8) \\
54(25.5)\end{array}$ & $\begin{array}{l}7(10.5) \\
10(14.9) \\
27(40.3) \\
23(34.3)\end{array}$ & 2.507 & 0.474 \\
\hline $\begin{array}{l}\text { Occupation } \\
\text { professional } \\
\text { civil servant } \\
\text { artisan } \\
\text { unemployed } \\
\text { farmer } \\
\text { others }\end{array}$ & $\begin{array}{l}39(18.4) \\
12(5.7) \\
56(26.4) \\
67(31.6) \\
25(11.8) \\
13(6.1)\end{array}$ & $\begin{array}{l}8(11.9) \\
2(3.0) \\
15(22.4) \\
16(23.9) \\
21(31.3) \\
5(7.5)\end{array}$ & & $0.016^{*}$ \\
\hline $\begin{array}{l}\text { Income } \\
\text { below poverty } \\
\text { line }(<19,500 \\
\text { Naira) } \\
\text { above poverty } \\
\text { line (> 19,500 } \\
\text { Naira) }\end{array}$ & $\begin{array}{l}44(30.3) \\
101(69.7)\end{array}$ & $\begin{array}{l}12(23.5) \\
39(76.5)\end{array}$ & 0.858 & 0.354 \\
\hline
\end{tabular}

* Fisher's exact test applied.

\begin{tabular}{|c|c|c|c|c|}
\hline \multirow[b]{2}{*}{ Variable } & \multicolumn{2}{|c|}{ Presence of depression } & \multirow[b]{2}{*}{$x^{2}$} & \multirow[b]{2}{*}{$p$} \\
\hline & $\begin{array}{l}\text { No } \\
n=212(\%)\end{array}$ & $\begin{array}{l}\text { Yes } \\
n=67(\%)\end{array}$ & & \\
\hline $\begin{array}{c}\text { Smoking } \\
\text { yes } \\
\text { no }\end{array}$ & \begin{tabular}{|l}
$6(2.8)$ \\
$206(97.2)$ \\
\end{tabular} & \begin{tabular}{|l|l}
$0(0.0)$ \\
$67(100.0)$ \\
\end{tabular} & & $0.341^{*}$ \\
\hline $\begin{array}{l}\text { Alcohol } \\
\text { yes } \\
\text { no }\end{array}$ & $\begin{array}{l}20(9.4) \\
192(90.6)\end{array}$ & $\begin{array}{l}14(20.9) \\
53(79.1)\end{array}$ & 6.249 & 0.012 \\
\hline $\begin{array}{l}\text { Other substance } \\
\text { yes } \\
\text { no }\end{array}$ & \begin{tabular}{|l|}
$3(1.4)$ \\
$209(98.6)$ \\
\end{tabular} & \begin{tabular}{|l|l}
$0(0.0)$ \\
$67(100.0)$ \\
\end{tabular} & & $0.437^{*}$ \\
\hline $\begin{array}{l}\text { Engaged in } \\
\text { sexual activities } \\
\text { yes } \\
\text { no }\end{array}$ & $\begin{array}{l}141(66.5) \\
71(33.5)\end{array}$ & $\begin{array}{l}47(70.2) \\
20(29.8)\end{array}$ & 0.306 & 0.580 \\
\hline $\begin{array}{l}\text { Always use } \\
\text { condoms? } \\
\text { always } \\
\text { never } \\
\text { sometimes }\end{array}$ & \begin{tabular}{|l|}
$82(58.6)$ \\
$13(9.3)$ \\
$45(32.1)$ \\
\end{tabular} & $\begin{array}{l}24(50.0) \\
10(20.8) \\
14(29.2) \\
\end{array}$ & 4.462 & 0.107 \\
\hline $\begin{array}{l}\text { Co-habitation } \\
\text { alone } \\
\text { with others }\end{array}$ & \begin{tabular}{|l}
$25(11.8)$ \\
$187(88.2)$ \\
\end{tabular} & $\begin{array}{l}17(25.4) \\
50(74.6) \\
\end{array}$ & 7.342 & 0.007 \\
\hline \begin{tabular}{|l} 
Disclosed status? \\
yes \\
no
\end{tabular} & $\begin{array}{l}186(87.7) \\
26(12.3)\end{array}$ & $\begin{array}{l}58(86.6) \\
9(13.4)\end{array}$ & 0.063 & 0.801 \\
\hline $\begin{array}{l}\text { If yes, to who? } \\
\text { partner } \\
\text { family } \\
\text { friends }\end{array}$ & \begin{tabular}{|l|}
$64(34.4)$ \\
$113(60.8)$ \\
$9(4.8)$ \\
\end{tabular} & $\begin{array}{l}18(31.0) \\
36(62.1) \\
4(6.9)\end{array}$ & & $0.740 *$ \\
\hline $\begin{array}{l}\text { Feel stigmatised? } \\
\text { yes } \\
\text { no }\end{array}$ & $\begin{array}{l}42(19.8) \\
170(80.2)\end{array}$ & $\begin{array}{l}25(37.3) \\
42(62.7)\end{array}$ & 8.546 & 0.003 \\
\hline
\end{tabular}

\begin{tabular}{|l|l|l|l|l|}
\hline $\begin{array}{l}\text { Family member } \\
\text { with HIV } \\
\text { yes } \\
\text { no }\end{array}$ & $\begin{array}{l}34(16.0) \\
178(84.0)\end{array}$ & $\begin{array}{l}18(26.9) \\
49(73.1)\end{array}$ & 3.936 & $\mathbf{0 . 0 4 7}$ \\
\hline $\begin{array}{l}\text { Personal history } \\
\text { of depression } \\
\text { yes } \\
\text { no }\end{array}$ & $\begin{array}{l}68(32.1) \\
144(67.9)\end{array}$ & $\begin{array}{l}42(62.7) \\
25(37.3)\end{array}$ & 19.97 & $<0.001$ \\
\hline $\begin{array}{l}\text { Family history of } \\
\text { depression } \\
\text { yes } \\
\text { no }\end{array}$ & $\begin{array}{l}7(3.3) \\
205(96.7)\end{array}$ & $\begin{array}{l}4(6.0) \\
63(94.0)\end{array}$ & & $0.303^{*}$ \\
\hline
\end{tabular}

* Fisher's exact test applied.

As shown in Table 3, there was no statistically significant relationship between depression and the HIV/Health-related characteristics of depression.

\begin{tabular}{|c|c|c|c|c|}
\hline \multirow[b]{2}{*}{ Variable } & \multicolumn{2}{|c|}{ Presence of depression } & \multirow[b]{2}{*}{$x^{2}$} & \multirow[b]{2}{*}{$p$} \\
\hline & $\begin{array}{l}\text { No } \\
n=212(\%)\end{array}$ & $\begin{array}{l}\text { Yes } \\
n=67(\%)\end{array}$ & & \\
\hline $\begin{array}{l}\text { How long are you } \\
\text { aware of your status? } \\
<1 \text { year } \\
1-5 \text { years } \\
6-10 \text { years } \\
>10 \text { years } \\
\end{array}$ & $\begin{array}{l}13(6.2) \\
77(36.3) \\
70(33.0) \\
52(24.5)\end{array}$ & $\begin{array}{l}6(9.0) \\
26(38.8) \\
24(35.8) \\
11(16.4) \\
\end{array}$ & 2.282 & 0.516 \\
\hline $\begin{array}{l}\text { Mode of infection } \\
\text { sex with the same } \\
\text { sex partner } \\
\text { sex with opposite } \\
\text { sex partner } \\
\text { injecting drugs } \\
\text { blood products } \\
\text { don't know } \\
\end{array}$ & $\begin{array}{l}23(10.9) \\
46(21.7) \\
1(0.5) \\
32(15.0) \\
110(51.9) \\
\end{array}$ & $\begin{array}{l}7(10.5) \\
22(32.8) \\
0(0.0) \\
11(16.4) \\
27(40.3) \\
\end{array}$ & & $0.345^{*}$ \\
\hline $\begin{array}{l}\text { Change in ART regi- } \\
\text { men in the last 3-6 } \\
\text { months } \\
\text { yes } \\
\text { no }\end{array}$ & $\begin{array}{l}29(13.7) \\
183(86.3)\end{array}$ & $\begin{array}{l}10(14.9) \\
57(85.1)\end{array}$ & 0.065 & 0.798 \\
\hline $\begin{array}{l}\text { How would you rate } \\
\text { your health? } \\
\text { very poor } \\
\text { poor }\end{array}$ & $\begin{array}{l}3(1.4) \\
3(1.4)\end{array}$ & $\begin{array}{l}0(0.0) \\
4(5.9)\end{array}$ & & $0.313^{*}$ \\
\hline $\begin{array}{l}\text { Neither good nor } \\
\text { poor } \\
\quad \text { good } \\
\text { very good } \\
\end{array}$ & $\begin{array}{l}14(6.6) \\
150(70.8) \\
42(19.8) \\
\end{array}$ & $\begin{array}{l}5(7.5) \\
46(68.7) \\
12(17.9)\end{array}$ & & \\
\hline $\begin{array}{l}\text { Duration on ARV } \\
\quad<1 \text { year } \\
1-5 \text { years } \\
6-10 \text { years } \\
>10 \text { years } \\
\end{array}$ & $\begin{array}{l}20(9.4) \\
80(37.8) \\
66(31.1) \\
46(21.7) \\
\end{array}$ & $\begin{array}{l}7(10.5) \\
32(47.7) \\
18(26.9) \\
10(14.9) \\
\end{array}$ & 2.800 & 0.424 \\
\hline $\begin{array}{l}\text { Adverse effect on } \\
\text { ARV } \\
\text { yes } \\
\text { no }\end{array}$ & $\begin{array}{l}45(21.2) \\
167(78.8)\end{array}$ & $\begin{array}{l}20(29.9) \\
47(70.1)\end{array}$ & 2.119 & 0.145 \\
\hline
\end{tabular}

* Fisher's exact test applied.

Table 4 shows the majority (73.1\%) had CD4 count $>350$, and $11.8 \%$ had CD4 count $<200$. The difference in the distribution of depression across the categories of CD4 count was not statistically significant.

Table 5 revealed that the farmers and the unemployed were 4 times and 1.26 times more likely to be depressed compared to 
the professionals. The odds of depression were 3.5 times higher in participants with a personal history of depression than those without. The participants who lived alone were 3 times more at risk of depression than those who lived with others. Stigmatisation almost doubled the odds of depression (1.95), while alcohol users were 1.54 times more likely to be depressed than non-users.

\begin{tabular}{|c|c|c|c|c|}
\hline \multirow[b]{2}{*}{ Variable } & \multicolumn{2}{|c|}{ Presence of depression } & \multirow[b]{2}{*}{$x^{2}$} & \multirow[b]{2}{*}{$p$} \\
\hline & $\begin{array}{l}\text { No } \\
n=212\end{array}$ & $\begin{array}{l}\text { Yes } \\
n=67\end{array}$ & & \\
\hline \multicolumn{5}{|l|}{ CD4 Count } \\
\hline$<200 / \mu l$ & $22(10.4)$ & $11(16.4)$ & 2.717 & 0.257 \\
\hline $200-350 / \mu \mathrm{l}$ & $30(14.1)$ & $12(17.9)$ & & \\
\hline$>350 / \mu l$ & $160(75.5)$ & $44(65.7)$ & & \\
\hline
\end{tabular}

Table 5. Binary logistic regression of factors that showed a significant relationship with depression

\begin{tabular}{|c|c|c|c|c|c|}
\hline \multirow[b]{2}{*}{ Variable } & \multirow{2}{*}{$\begin{array}{l}\text { Presence of } \\
\text { depression } \\
\text { (Yes) }\end{array}$} & & \multicolumn{2}{|l|}{$95 \% \mathrm{Cl}$} & \multirow[b]{2}{*}{$p$} \\
\hline & & OR & Lower & Upper & \\
\hline Alcohol & \begin{tabular}{|l} 
yes \\
no
\end{tabular} & $\begin{array}{l}1.54 \\
1.0 \text { (R.C) }\end{array}$ & 0.62 & 3.82 & 0.036 \\
\hline Occupation & \begin{tabular}{|l} 
professional \\
civil servant \\
artisans \\
unemployed \\
farmer \\
others \\
\end{tabular} & $\begin{array}{l}1.0 \text { (R.C) } \\
1.10 \\
1.40 \\
1.26 \\
4.01 \\
3.59 \\
\end{array}$ & \begin{tabular}{|l|}
0.16 \\
0.47 \\
0.43 \\
1.37 \\
0.83 \\
\end{tabular} & \begin{tabular}{|l}
5.85 \\
4.01 \\
3.63 \\
11.78 \\
15.4 \\
\end{tabular} & \begin{tabular}{|l|}
0.987 \\
0.054 \\
$\mathbf{0 . 0 4 1}$ \\
$\mathbf{0 . 0 1 1}$ \\
0.085 \\
\end{tabular} \\
\hline Cohabitation & \begin{tabular}{|l} 
alone \\
with others
\end{tabular} & $\begin{array}{l}3.21 \\
1.0 \text { (R.C) }\end{array}$ & 1.43 & 7.60 & 0.025 \\
\hline $\begin{array}{l}\text { Stigmatisa- } \\
\text { tion }\end{array}$ & $\begin{array}{l}\text { yes } \\
\text { no }\end{array}$ & $\begin{array}{l}1.95 \\
1.0 \text { (R.C) }\end{array}$ & 0.92 & 3.70 & 0.008 \\
\hline $\begin{array}{l}\text { Personal } \\
\text { history of } \\
\text { depression }\end{array}$ & $\begin{array}{l}\text { yes } \\
\text { no }\end{array}$ & $\begin{array}{l}3.50 \\
1.0 \text { (R.C) }\end{array}$ & 1.75 & 6.38 & $<0.001$ \\
\hline $\begin{array}{l}\text { Family } \\
\text { member } \\
\text { with HIV }\end{array}$ & $\begin{array}{l}\text { yes } \\
\text { no }\end{array}$ & $\begin{array}{l}2.10 \\
1.0 \text { (R.C) }\end{array}$ & 0.97 & 4.53 & 0.057 \\
\hline
\end{tabular}

\section{Discussion}

The findings from this study suggest a marked burden of depression (24\%), which was significantly associated with alcohol intake, stigmatisation, cohabitation, occupational types and personal history of depression amongst PLWHA in the study setting. The depression prevalence of $24 \%$ in this study was similar to the rates reported in previous studies in Nigeria [9, 12, 20,21 , as well as within the range of $20 \%$ to $30 \%$ reported in some African countries $[11,22]$ and $20 \%$ reported in Australia [23]. However, a higher prevalence of $39.1 \%$ and $57 \%$ was observed in similar studies in southeast and north central Nigeria, respectively $[13,24]$. The differences in prevalence rates may be a reflection of the geographical variations in the epidemiology of diseases in Nigeria. A meta-analysis in Ethiopia reported a higher prevalence of $36.6 \%$ [25]. The author reported that this finding was similar to other low-income countries [25]. The high prevalence of depression may also be explained by the challenges of coping with the diagnosis, disease symptoms, bereavement, relationship crises, social rejection, co-existing poverty and the side effects of certain antiretroviral medications [26].
Farmers were 4 times more likely to be depressed compared to professionals (such as teachers, lawyers, bankers). $80 \%$ of the farmers in this study lived below the poverty line; therefore, their higher odds of being depressed may be connected to their economic situation. Unemployed participants were 1.26 times more likely to be depressed compared to professionals. This might be because a medium or high socioeconomic status promotes access to the required health services and information among professionals. Likewise, a cross-sectional study in South Africa reported that unemployment could cause mental and physical hardships [27]. In contrast to the findings in this study, PLWHA who were employed were twice as likely to be depressed compared with their unemployed counterpart in a study carried out in Benin city, Nigeria [5]. Furthermore, unemployment may correlate with poorer quality of life outcomes, which are related to poor psychological adjustment. Discrimination by employers was reported to affect the disclosure of status by affected individuals, which affects the effectiveness and attention they pay to receiving optimal care [21].

Alcohol intake, cohabitation, experience of stigma and a personal history of depression had statistically significant associations with depression [28]. Among PLWHA, alcohol abuse is associated with depression, non-adherence to medication, as well as an increased risk of engaging in risky behaviour [29,30]. This study did not screen for alcohol abuse; however, the history of alcohol intake among the participants was significantly related to depression.

Participants who were stigmatised were twice as likely to be depressed as those who were not. Similarly, this stigma had a statistically significant association with depression in a study in northeast Nigeria, which compared depression, self-stigma and quality of life among adult patients on highly active antiretroviral therapy (HAART) and diabetics [31]. This was also in concordance with a study in Ethiopia [32] and south India [33]. These studies reported that PLWHA who were accessing ART services were significantly more likely to experience severe stigma [32, 33].

Participants who lived alone were about 3 times more likely to be depressed than those who lived with others. Similarly, a study in a tertiary hospital in southeast Nigeria evaluated depression among PLWHA and reported that living with others is significantly protective against having a depressive illness [21]. The author suggested that the extended family system played a supportive role. It may be that it reduces hopelessness and helplessness, which are key constructs in the diagnosis of depression [17]. Family members provide support, which reduces stigma and reduces the risk of psychological maladjustment [21].

Concerning treatment outcome measures, there was no statistically significant relationship between the CD4 counts of the participants and the occurrence of depression. This was in agreement with the findings from a study in Sao Paulo, Brazil, which evaluated depression in 46 HIV/AIDS in-patients admitted to the hospital of infectious disease [34]. Likewise, a study in India estimating the prevalence and factors associated with depression among clinically stable PLWHA on ART also found no association between the CD4 counts of the participants and depression [35]. This was also in concordance with a report from a cross-sectional study done in China [36]. However, a contrary finding from a study in northern Nigeria supported the association between depressive disorder and CD4 count. Patients with CD4 counts $<150$ cells $/ \mu$ l were more likely to be depressed [15]. It may be inferred from these differences that psychosocial factors (such as stigma, cohabitation, isolation) have a stronger association with depression among PLWHA than the clinical outcome (CD4).

\section{Limitations of the study}

The cross-sectional nature of this study may limit the cause-and-effect interpretation of the factors observed. Since the study was hospital-based, it might not be generalisable to the total population of people living with HIV in the study environment. 


\section{Recommendations}

A community-based study is recommended to yield findings that can be generalisable to the entire population.

Given the high prevalence of depression among patients with HIV/AIDS, mental health services should be an integral part of services offered to PLWHA.

National policies on intervention among PLWHA should be refocused to addressing social problems.

\section{Conclusions}

The burden of depression is high among PLWHA in the study setting, with behavioural and psychosocial factors being the major predictors of depression. Physicians play a vital role in identifying these patients and eliciting the specific factors associated with the occurrence of depression in them.

The findings from this study highlight the need for advocacy to ensure the incorporation of mental health care in HIV related programmes.

Source of funding: This work was funded from the authors' own resources.

Conflicts of interest: The authors declare no conflicts of interest.

\section{References}

1. Owe-Larsson B, Sall L, Salamon E, et al. HIV infection, and psychiatric illness. Afr J Psychiatry (Johannesburg) 2009; 12: 115-128.

2. Mathers CD, Loncar D. Projections of global mortality and burden of disease from 2002 to 2030. Plos Med 2006; 3(11): $2011-2030$.

3. World Health Organisation. Health topics: Depression [cited 5.10.2017]. Available from URL: https://www.who.int/health-topics/ depression\#tab=tab_1.

4. Fekadu A, Medhin G, Selamu M, et al. Recognition of depression by primary care clinicians in rural Ethiopia. BMC Fam Pract 2017; 18(1): 56.

5. Chikezie U, Otakpor AN, Kuteyi O, et al. Depression among people living with human immunodeficiency virus infection/acquired immunodeficiency syndrome in Benin City, Nigeria: a comparative study. Niger J Clin Pract 2013; 16(2): 238-242.

6. Rasbkin JG. HIV and depression: 2008 review and update. Curr HIV/AIDS Rep 2008; 5: 163-171.

7. Munjal S. Prevalence of depression in people living with HIV/AIDS undergoing ART and factors associated with it. J Clin Diagnostic Res 2014; 94: 1-4.

8. Obi I, Aniebue P, Okonkwo K, et al. Prevalence of depression among health workers in Enugu, South East Nigeria. Niger J Clin Pract 2015; 18(3): 342-347.

9. Ndu A, Arinze-Oniya S, Aguwa E, et al. Prevalence of depression and role of support groups in its management: a study of adult HIV/ /AIDS patients attending HIV/AIDS Clinic in a tertiary health facility in. J Public Heal Epidemiol 2011; 3: 182-186.

10. Cassano P, Fava M. Depression and public health: an overview. J Psychosom Res 2002; 53: 849-857.

11. Pappin M, Wouters E, Booysen FL. Anxiety and depression amongst patients enrolled in a public sector antiretroviral treatment programme in South Africa: a cross-sectional study. Biomed Cent 2012; 12(244): 2-9.

12. Obadeyi A, Ogunlesi A, Adebowale T. Prevalence and predictor of depression in people living with HIV/AIDS attending an outpatient clinic in Nigeria. Iran J Psychiatry Behav Sci 2014; 8(1): 26-30.

13. Aguocha $\mathrm{CM}$, Uwakwe RU, Duru CB, et al. Prevalence and socio-demographic determinants of depression among patients attending HIV/AIDS Clinic in a Teaching Hospital in Imo State, Nigeria. Am J Med Sci Med 2015; 3(6): 106-112.

14. Investing in mental health: evidence for Action. WHO; 2013; 9-22 [cited 1.08.2018]. Available from URL: http://www.apps.who.int.

15. Olisah V, Adekeye O, Sheikh T. Depression, and CD4 count among patients with HIV in a Nigerian University Teaching Hospital. Int J Psychiatry Med 2015; 48(4): 253-261.

16. Sale S, Gadanya M. Prevalence and factors associated with depression in HIV/AIDS patients aged 15-25 years at Aminu Kano Teaching Hospital Nigeria. Niger J Child Adolesc Ment Heal 2008; 20: 85-89.

17. Cochran WG. Sampling techniques. 2nd ed. New York: John Wiley \& Sons, Inc.; 1963.

18. Araoye M. Research methodology with statistics for health and social sciences. Ilorin: Nathadex Publishers Ilorin; 2004: 25-120.

19. Adewuya A, Ola B, Afolabi O. Validity of the Patient Health Questionnaire (PHQ-9) as a screening tool for depression among Nigerian university students. J Affect Disord 2006; 96: 89-93.

20. Olisah VO, Baiyewu O, Sheikh TL. Adherence to highly active antiretroviral therapy in depressed patients with HIV/AIDS attending a Nigerian university. African Journal Psychiatry 2010; 13: 275-279.

21. Chikezie U, Otakpor AN, Kuteyi O, et al. Depression among people living with human immunodeficiency virus infection/acquired immunodeficiency syndrome in Benin City, Nigeria: a comparative study. Niger J Clin Pract 2013; 16(2): 238-242.

22. Brandt R. The mental health of people living with HIV/AIDS in Africa: a systematic review. African J AIDS Res 2010; 8(2): 123-133.

23. Mao L, Kippax S, Newman C, et al. Rates of depression among men attending high-HIV-caseload general practices in Australia. Ment Health Fam Med 2008; 5: 79-83.

24. Shittu R, Issa B, Olanrewaju G, et al. Prevalence and correlates of depressive disorders among people living with HIV/AIDS, in North Central Nigeria. J AIDS Clin Res 2013; 4(11): 1-7.

25. Amare T, Getinet $\mathrm{W}$, Shumet $\mathrm{S}$, et al. Prevalence and associated factors of depression among PLHIV in Ethiopia: systematic review and meta-analysis; 2017. AIDS Res Treat 2017; 20(18): 1-10.

26. Abas M, Ali G, Nakimuli-mpungu E, et al. Depression in people living with HIV in sub-Saharan Africa: time to act. Trop Med Int Heal 2014; 19(12): 1392-1396.

27. Bongongo T, Tumbo J. Depressive features among adult patients receiving antiretroviral therapy for HIV in Rustenburg district, SA. South African J Psychiatry 2013; 19(2): 31-41.

28. Williams E, Bradley $\mathrm{K}$, Balderson B, et al. Alcohol and associated characteristics among older persons living with HIV on antiretroviral therapy. Subst Abus 2014; 35(3): 245-253.

29. Molina PE, Bagby GJ, Nelson S. Biomedical consequences of alcohol use disorders in the HIV- infected host invited review. Curr HIV Res 2014; 12(4): 265-275.

30. Wakawa IA, Sale S, Kwajafa SP, et al. Depression, self-stigma and quality of life: a comparative analysis of adults on Highly Active Antiretroviral Therapy (HAART) and diabetics in a Tertiary Health Institution in Northeastern Nigeria. Int Invent Journals 2014; 1(4): 50-59.

31. Mohammed M, Mengistie B, Dessie Y, et al. Prevalence of Depression and Associated Factors among HIV Patients Seeking Treatments in ART Clinics at Harar Town, Eastern Ethiopia. J AIDS Clin Res 2015; 6(6): 1-6.

32. Eshetu DA, Meseret S, Gizachew KD. Prevalence of depression and associated factors among HIV/AIDS patients attending ART Clinic at Debrebirhan Referral Hospital, North Showa, Amhara Region, Ethiopia. Clin Psychiatry 2015; 1(1): 1-7. 
33. Bimal C, Jeyaseelan L, Pandian A, et al. Association between stigma, depression, and quality of life of people living with HIV/AIDS (PLWHA) in South India - a community-based cross-sectional study. BMC Public Health 2012; 12(1): 463.

34. Capitão CG, Finotelli I Jr., Macena CS de. Evaluation of depression and anxiety on HIV/AIDS in-patient. J AIDS HIV Res 2011; 3(12): $240-246$.

35. Algoodkar S, Kidangazhiathmana A, Rejani PP, et al. Prevalence and factors associated with depression among clinically stable people living with HIV/AIDS on antiretroviral therapy. Indian J Psychol Med 2017; 39(6): 789-793.

36. Liu L, Pang R, Sun W, et al. Functional social support, psychological capital, and depressive and anxiety symptoms among people living with HIV / AIDS employed full-time. BMC Psychiatry 2013; 13(324): 1-10.

Tables: 5

Figures: 0

References: 36

Received: 16.09.2019

Reviewed: 8.05.2020

Accepted: 1.09.2020

Address for correspondence:

Olawunmi A. Olagundoye, MD

1-3 Board Street

Lagos Island 23401

Nigeria

Tel.: +234 8057641220

E-mail address: olabima@yahoo.com; olawunmiolagundoye@gmail.com 